\section{Ks. Maciej Dżugan}

Katolicki Uniwersytet Lubelski Jana Pawła II, Lublin macdzug@gmail.com

DOI: http://dx.doi.org/10.12775/BPTh.2015.024

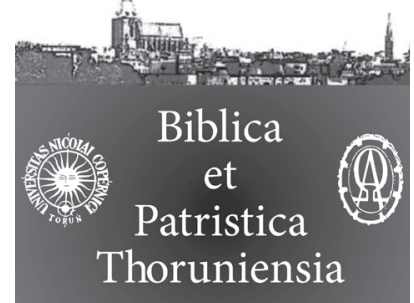

8 (2015) 4: 23-38

ISSN (print) 1689-5150

ISSN (online) 2450-7059

\title{
Dlaczego Rachab została ocalona, a Akan stracony? Deuteronomiczne rozumienie nakazu zagłady (herem) w świetle Księgi Jozuego
}

\section{Why Rahab was saved and Akan lost? Deuteronomy understanding of the order of destruction (herem) in the light of the Book of Joshua}

Streszczenie. Instytucja wojny Jahwe oraz prawo heremu są jednym z najbardziej kontrowersyjnych zagadnień w Biblii. Księga Jozuego, będąca opisem podboju Kanaanu, często do tej koncepcji nawiązuje. Na tle opisów podboju Kanaanu szczególne miejsce zajmują narracje o Rachab i Akanie, które są odstępstwem w instytucji wojny Jahwe, a w szczególności prawa ḥeremu. Praca na podstawie narracji próbuje wskazać motywy i przyczyny zachowania od ḥeremu poganki Rachab i ukarania klątwą wojownika izraelskiego Akana.

\begin{abstract}
The institution of the Yahweh's war and the law of ban are one of the most controversial issues in Bible. The Book of Joshua, as description of the conquest of Canaan often hard back to this concept. Against the background of the conquest's descriptions of Canaan, the narrations about Rachab and Achan occupy special place and they are an exception in the procedure of the holy war, in particularly in the law of ban. On the basis of these narrations, the article tries to indicate motifs and reasons of rescue of the pagan Rachab from the curse and the punishment of the Israel's warrior Achan.
\end{abstract}

Słowa kluczowe: Rachab; Akan; herem; klątwa; Jozue.

Keywords: Rahab; Achan; ḥerem; ban; Joshua.

$\mathrm{K}$

sięga Jozuego stanowiąca część historiografii deuteronomistycznej jest teologicznym opracowaniem procesu podboju Kanaanu. Redaktor deuteronomistyczny na bazie wydarzeń historycznych skonstruował narrację o pochodzie niezwyciężonego i wszechmocnego Boga Jahwe, który spełniając swo- 
je obietnice, daje Izraelowi ziemię obiecaną ${ }^{1}$. Taka historyczno-teologiczna konwencja księgi pozwala redaktorowi swobodnie prezentować podstawowe zagadnienia teologii deuteronomicznej i deuteronomistycznej, wśród których dominuje: koncepcja idealnej teokracji, czystość kultu Jahwe, obietnica ziemi, wierność prawu i przymierzu, jedność narodu oraz problematyczna idea wojny Jahwe ${ }^{2}$.

\section{Instytucja wojny Jahwe}

Zagadnienie wojny Jahwe, nazywanej również świętą wojną, wzbudza liczne kontrowersje natury teologicznej i moralnej ${ }^{3}$. Próba sprowadzenia instytucji świętej wojny w Biblii do fikcji literackiej, w świetle uwarunkowań historycznych i kulturowych ludów Bliskiego Wschodu wydaje się mało prawdopodob$\mathrm{na}^{4}$. Wobec autentyczności instytucji wojny Jahwe, aktualne jest pytanie o łączenie Boga z okrucieństwem wojny oraz moralne aspekty praktyk wojennych, w szczególności niezwykle surowego z punktu widzenia etyki chrześcijańskiej prawa heremu. Kwestie te skłaniają do pochylenia się nad przesłaniem tekstu natchnionego, jak również pogłębionej refleksji egzegetycznej i teologicznej opisów biblijnych.

Schemat instytucji wojny Jahwe został nakreślony w Pięcioksięgu i historiografii deuteronomistycznej jako określony rytuał, seria obrzędów, które nie zawsze występują kolektywnie, czasem wybiórczo, niemniej jednak tworzą opis biblijny praktyki nazwanej wojną Jahwe.

1 Kwestia historyczności opisu podboju Kanaanu w Księdze Jozuego budzi wiele wątpliwości, szczególnie w świetle odkryć archeologicznych. Römer, de Pury, Deuteronomistic historiography (dh), 24-25; Curtis, Joshua, 54-59; Strange, The Book of Joshua, 44-51.

2 Sicre, Giosuè, 37-39; Dziadosz, Teokratyczna historiografia Izraela, 8-23.

3 Choć stosowane sformułowanie „święta wojna” w odniesieniu do wojny Jahwe, budzi skojarzenie z ideologią wojny w religii muzułmańskiej, niemniej jednak nazwa ta podkreśla wymiar religijny i kultyczny instytucji wojny w Izraelu. Rowlett, Joshua and the Rhetoric of Violence, 51-65; Craigie, The Problem of War, 48-50.

4 Teza, że rytuał wojny świętej jest czysto literackim, fikcyjnym zabiegiem autorów jest mało prawdopodobna. Wydaje się jednak, że właściwszym podejściem jest koncepcja zakładająca, że instytucja wojny Jahwe jest przepracowaniem teologicznym wydarzeń historycznych. Taki pogląd potwierdza znajomość instytucji świętej wojny u narodów ościennych (Asyryjczyków, Egipcjan). Poza tym w kulturze Bliskiego Wschodu wojna zawsze posiadała nie tylko charakter militarny, lecz również kultyczny, powiązany z licznymi rytuałami czy obrzędami. Lind, Yahweh Is a Warrior, 24-31; Jones, The Concept of Holy War, 299-302. 
Instytucja wojny Jahwe opiera się na fundamentalnym założeniu, że walka nie toczy się pomiędzy Izraelitami a ich wrogami, lecz pomiędzy Jahwe, Bogiem Izraela i jego przeciwnikami, przy mniejszym lub większym udziale narodu wybranego ${ }^{5}$. Prawda o obecności Boga Izraela pośród swego ludu jest wyrażona wieloaspektowo w tekstach biblijnych. Zgromadzony do walki lud nazwany jest 'am-yhwh „ludem Jahwe” (Sdz 5,11) lub ma 'arkôt élōhîm „wojskiem Boga” (1 Sm 17,26.45-46). Izrael, jako naród uświęcony obecnością Jahwe zostaje wezwany do oczyszczenia rytualnego ( $q \bar{a} \underline{d} a \underline{s}$, Wj 19,10-14; Joz 3,5), do powstrzymania się od pożycia seksualnego (1 Sm 21,5; 2 Sm 11,11-12) oraz do złożenia ślubów (Lb 21,2; $1 \mathrm{Sm}$ 14,24) i ofiar (1 Sm 7,9; 13,9-10) przed walką ${ }^{6}$. Konkretnym symbolem obecności Jahwe pośród ludu jest również arka przymierza, obecna zarówno w obozie Izraelskim, jak i na polu walki (Joz 3,6-11; 6,6-13)7.

Centralna rola Jahwe, jako wojownika i zdobywcy, który realizuje swoje obietnice zostaje podkreślona przede wszystkim przez formułę powierzenia ziemi: nātattî baya $\underline{a} \underline{d} \underline{k} a$,ja daję w twoje ręce” (Joz 8,1; Sdz 4, 7; 7,9) oznajmiana przez Jahwe bądź przez pośrednika wskazuje dokładnie, kto odgrywa decydującą rolę w walce. Przez to bitwa staje się wojną Jahwe (milhămôt $y h w h$, Wj 17,16; Lb 21,14; $1 \mathrm{Sm}$ 18,17), a przeciwnicy Izraela, wrogami Jahwe ('oyəobê

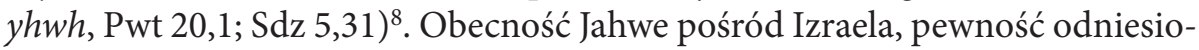
nego zwycięstwa oraz postawa wojownika walczącego w imieniu, a niejednokrotnie zamiast swego ludu, wywołuje niezmierzoną radość u Izraelitów, często wyrażaną w radosnym okrzyku (tərû 'āh, $\mathrm{Sdz} 7,20 ; 1 \mathrm{Sm} 4,5)^{9}$ oraz strach i bojaźń w szeregach wroga (mû̄g, 'êmāh, māsas; Wj 23,27-28; Joz 2,9-11) ${ }^{10}$.

Kluczowym elementem instytucji wojny Jahwe jest prawo ḥeremu, którego doktryna została zarysowana w Księdze Powtórzonego Prawa. Słowo ḥērem „rzecz poświęcona, klątwa” związane ściśle z czasownikiem hāram „poświęcić, obłożyć klątwą, zniszczyć zupełnie”, wskazuje na osobę lub przedmiot wyłączony z użytku świeckiego i oddany Bogu ${ }^{11}$. Prawo ḥeremu posiada dwa znaczenia: bardziej pierwotne wskazuje na zabarwienie religijne, kultyczne tego

5 Craigie, The Problem of War, 33-36; Lind, Yahweh Is a Warrior, 24-25.

6 von Rad, Holy War in Ancient Israel, 41-43; de Vaux, Instituciones del Antiguo Testamento, 347.

7 Miller, The Divine Warrior, 143-154; de Vaux, Instituciones del Antiguo Testamento, 347-348.

8 Jones, The Concept of Holy War, 299, 312-313; von Rad, Holy War in Ancient Israel, 44.

9 Humbert, La «Terou'a», 29-30, 37-45; Schwienhorst, Die Eroberung Jerichois, 52.

10 McCarthy, Some Holy War, 228-300.

11 Lohfink, «hāram», THDOT, t. V, 184. 
słowa, a zarazem prawa (Wj 22,19-20; Kpł 27,20-29), które z czasem przyjęło zabarwienie militarne, oznaczające anihilacje wroga oraz zniszczenie jego dobytku (Lb 21,2; Pwt 2,34; Joz 2,10) ${ }^{12}$. Nakaz ḥeremu jest ściśle związany z przymierzem barît, tak bardzo, że złamanie prawa ḥeremu jest równoznaczne ze złamaniem całego przymierza (Joz 7,11).

Tekstami ustanawiającymi prawo heremu są dwa fragmenty biblijne: Pwt 7,1-6 oraz 20,10-18, których fundamentalnym przesłaniem, pomimo pewnych drobnych różnic, jest nakaz anihilacji autochtonicznej ludności Kanaanu: Chetytów, Girgaszytów, Amorytów, Kananejczyków, Peryzzytów, Chiwwitów i Jebusytów oraz ich dobytku (Pwt 7,1-2; 20,17) ${ }^{13}$. Pierwszy fragment dokładnie precyzuje zachowanie Izraelitów, nakazując bezwzględną anihilację pogan, bez okazania jakiejkolwiek litości, zakazuje zawierania przymierza i małżeństw mieszanych, a ponadto zarządza zniszczenie wszystkich przedmiotów kultu bałwochwalczego (Pwt 7,3-4.5). Drugi fragment (Pwt 20,10-18) kładzie wprawdzie nacisk na bezwzględność prawa ḥeremu, jednak dostrzegalna jest pewna liberalizacja tego nakazu. Rozkaz heremu obowiązuje względem miast i terytoriów gdzie mają zamieszkać Izraelici, natomiast wobec miast oddalonych, dopuszczone są pertraktacje pokojowe, zawarcie pokoju, po uprzedniej ich kapitulacji (Pwt 20,10-11). Opór mieszkańców miasta, nawet odległego, brak chęci poddania się lub zawarcia pokoju, przywraca nakaz wytracenia wszystkich mężczyzn, pozostawiając jednak przy życiu kobiety i dzieci, oraz zwierzęta i wszelkie bydło, które Izraelici wezmą w posiadanie (Pwt 20,12-15).

Powyższe passusy biblijne, uzasadniając prawo ḥeremu, poddają motyw religijny i kultyczny, a więc troskę o czystą i nienaruszoną wiarę w Boga Jahwe oraz zdecydowane odrzucenie wszelkich form bałwochwalczych lub takich relacji, które do bałwochwalstwa mogą prowadzić (Pwt 7,4-6; 20,18) ${ }^{14}$.

Wprawdzie pewne elementy wojny Jahwe odnotować można już w Pięcioksięgu (Wj 14,1-15,21; Pwt 3,1-7), to jednak temat ten zostaje w pełni rozwinięty i pogłębiony przez redaktora deuteronomistycznego w Księdze Jozuego, szczególnie w pierwszej części Księgi (Joz 1-12), w której opisane są przygotowania i sam podbój Kanaanu.

12 Lilley, Understanding the Herem, 173-176.

13 Hoffman, The Deuteronomistic Concept of the Herem, 196.

14 Craigie, The Problem of War, 45-47. 


\section{Dwa wyjątki}

Wśród licznych opisów podboju Palestyny, prezentujących ideę wojny Jahwe dwie historie wydają się przekraczać standardowe ramy tej instytucji, a nawet wręcz zaskakiwać. Historia poganki i nierządnicy Rachab $(2,1-24 ; 6,1-27)$ oraz historia wojownika izraelskiego Akana $(7,1-26)$ są znaczącym wyjątkiem w założeniach instytucji wojny Jahwe, a przede wszystkim w zachowaniu przykazania heremu. Rachab jako poganka mieszkająca w mieście, które stawia opór narodowi wybranemu, powinna zostać zgładzona zgodnie z prawem, a mimo to zawiera przymierze $\mathrm{z}$ Izraelem. Akan natomiast jako wojownik izraelski, walczący w imieniu Boga, zostaje poddany anihilacji za swój niecny występek. Choć na pozór te dwa wątki wydają sie bardzo różne od siebie, to przy głębszej analizie można wykazać pewne podobieństwo.

Przede wszystkim obydwie postacie związane są ze zdobyciem miasta Jerycha: Rachab jest mieszkanką miasta, nierządnicą $(2,1)$, natomiast historia Akana choć rozgrywa się w kontekście nieudanego podboju Aj, jednak swoją genezę ma w przewinieniu, którego dopuścił się w czasie kampanii przeciw Jerychu $(7,1)$. Rachab, w zamian za pomoc udzieloną wywiadowcom, zostaje ocalona razem ze swoją rodziną $(6,23)$, Akan za swoje przewinienie zostaje stracony wraz z rodziną (7,24-25). Rachab zawiera przymierze z Izraelem (6,17-20), Akan łamie przymierze $\mathrm{z}$ Jahwe $(7,11)$, Rachab okazuje miłosierdzie i pomoc wywiadowcom $(2,12)$, Akan przez swoje postępowanie wprowadził cały naród w kłopoty $(7,11.25)^{15}$.

Umieszczenie tych dwóch historii w pierwszych rozdziałach Księgi Jozuego oraz szczegółowy i obszerny charakter narracji sugeruje, że redaktor deuteronomistyczny, konstruując swoje dzieło, nadał szczególne znaczenie tym dwóm wątkom ${ }^{16}$. Wydaje się, że skoro te dwa opowiadania są tak wyraźnym odstępstwem od instytucji wojny Jahwe, a zwłaszcza prawa heremu, to celem redaktora deuteronomicznego, jest przewartościowanie, pogłębienie i nadanie nowego wyrazu teologicznego koncepcji idei świętej wojny. Przyjęcie takiego zamiaru autora, domaga się spojrzenia na te dwie historie przez pryzmat instytucji wojny Jahwe.

15 Hamlin, Inheriting the Land, 19-20.

16 Warto zauważyć, że historia Rachab jak również opis tragicznego losu Akana i jego rodziny kończy się stwierdzeniem etiologicznym 'a d hayyôm hazzeh „aż po dzień dzisiejszy” $(6,25 ; 7,26)$. Newman, Rahab and the Conquest, 174; Geoghegan, «Until This Day», 201-227. 


\section{Ocalona Rachab}

Chociaż obszerna narracja o Rachab obejmuje fragment 2,1-24, to występuje ona w kontekście tematu przewodniego, jakim jest motyw podboju Jerycha. To właśnie w opisie zdobycia miasta jej historia znajduje swoją kontynuację i epilog $(6,1-27)$. Opis podboju miasta pozwala głębiej zrozumieć przesłanie teologiczne, które zawiera historia o wywiadowcach w Jerychu. Wśród narracji o podboju Kanaanu, historia podboju Jerycha $(6,1-27)$ jest wręcz wzorcowym opisem instytucji wojny Jahwe, w którym są zawarte elementy charakterystyczne dla tej deuteronomistycznej koncepcji.

Już pierwsze wersety narracji wskazują, że wprawdzie Jerycho zamknięte jest przed Izraelem, ale głównym przeciwnikiem i wojownikiem, z którym muszą walczyć mieszkańcy miasta, jest Bóg Jahwe (Joz 6,1-2) ${ }^{17}$. Nadrzędna rola Jahwe $\mathrm{w}$ walce przeciw miastu oraz Jego obecność pośród Izraela zostaje zaakcentowana przez wiele elementów. Przede wszystkim obecność Boga zostaje uwydatniona już $\mathrm{w}$ momencie przygotowań do podboju poprzez nakaz oczyszczenia ludu: hițqaddāšû (Joz 3,5). Pojawia się on znacznie wcześniej, przed przekroczeniem Jordanu przez Izraela, będącym symbolicznym aktem rozpoczęcia podboju ziemi obiecanej ${ }^{18}$. Bóg Izraela $w$ formule powierzenia: nātattî bəyā $\underline{d} \underline{k} \bar{a}$ 'et-yarîhô $(6,2)$, daje miasto w ręce Izraelitów. Jahwe odgrywa również decydującą rolę w podboju miasta. Symbolem stałej Jego obecności oraz wojennego zaangażowania w kampanię przeciwko Jerychu jest arka przymierza, która przebywa w obozie izraelskim, a jednocześnie stanowi istotny element w procesji wokół murów miasta (6,4.6-8.11-13). Izraelici natomiast tylko symbolicznie partycypują w podboju miasta. Ich względne zaangażowanie ogranicza się do posłuszeństwa Jozuemu, uczestniczeniu w liturgicznych procesjach $\mathrm{z}$ arką przymierza wokół miasta (sāb $\underline{b} a \underline{b} ; 6,3-7.11-15)$ oraz wzięcia go w posiadanie ('âlāh , lāk $\underline{k} a \underline{d}$ ), kiedy w sposób cudowny upadają jego mury $(6,20)^{19}$. Obecność Jahwe zostaje również podkreślona przez granie na trąbach šôpar (6,4-9.13-20), jak również krzyk radości tərû'āh (6,6.20), które są ważnym elementem procesji Izraelitów wokół miasta oraz sygnałem do rozpoczę-

17 Harstad, Joshua. The People's Bible, 89; Woudstra, The Book of Joshua, 109.

18 Miller, The Divine Warrior, 157.

19 Tekst natchniony opisując upadek murów miasta używa wyrażenia wattippōl hahômāh tahteyhā, które można przetłumaczyć "upadł mur na tym samym miejscu". To wyrażenie ma na celu podkreślić prawdę, że mury upadły bez jakiejkolwiek ludzkiej ingerencji, a całe wydarzenie należy uznać za cudowne. «tahat», BDB, 1165; Butler, Joshua. The Conqueror of Canaan, 129-131. 
cia ataku ${ }^{20}$. Wyraźnie zaakcentowany jest również nakaz ḥeremu wydany przez Jozuego $(6,17-18)$ oraz wykonany przez Izraelitów z zastrzeżeniem, że srebro, złoto oraz sprzęty z brązu i żelaza miały zostać przekazane do skarbca domu Pańskiego (6,21.24).

W historii podboju Jerycha, dostrzegalne jest jednak znaczące odstępstwo od instytucji wojny Jahwe, przede wszystkim od prawa heremu. Rachab, która ze względu na swoje pogańskie pochodzenie powinna zostać poddana klątwie zostaje zachowana przy życiu $(6,17.22 .25)$. Takie postępowanie Izraelitów wydaje się zupełnie niezrozumiałe w świetle nakazu ḥeremu, a nawet może zostać zakwalifikowane, jako nieposłuszeństwo $\mathrm{Bogu}^{21}$. Tekst podaje wprawdzie, nawet dwukrotnie, konkretną przyczynę ocalenia Rachab: kî heḥbə'ațāh ' et-hammalə’akîm $(6,17.25)$, wskazując, że ukryła wywiadowców, wysłanych przez Jozuego do Jerycha, jednak samo uzasadnienie ma tylko charakter informacyjny i nie rozwiewa do końca wątpliwości związanych z przestrzeganiem prawa i przymierza (Pwt 7,2)22. Opis dalszych losów Rachab i jej rodziny, naznaczony jest pewnym dysonansem: $z$ jednej strony redaktor deuteronomiczny zaznacza, że została umieszczona poza obozem Izraela, z drugiej - podaje, że zamieszkała pośród Izraela, co byłoby konkretnym znakiem zawarcia przymierza i przynależności do narodu wybranego ${ }^{23}$.

Pogłębiona refleksja nad motywem podanym w Joz 6,17.23-25 wymaga sięgnięcia do opowiadania o wywiadowcach w Jerychu (2,1-24), w którym zachowanie Rachab oraz jej intencje są szeroko zaprezentowane. Narracja ta opisuje czyn Rachab w sposób o wiele bardziej złożony. Rachab nie tylko ogranicza się do ukrycia wywiadowców $(2,4.6)$, lecz także ona ich przyjmuje $(2,1)$, narażając własne życie, chroni ich, okłamując ludzi króla (2,3-4), kieruje pościg na fałszywy trop $(2,5)$, pomaga szpiegom wydostać sie z miasta, gdy bramy są

20 Zarówno granie na trąbach, jak i wznoszony krzyk posiadają wieloaspektowe znaczenie. Są znakiem teofanii i obecności Jahwe (Wj 19,16.20; 1Sm 4,6; Jr 20,16; 50,15; Ez 21,27), posiadają zabarwienie kultyczne (2Sm 6,15 Ezd 3,11.13; Ps 27,6) oraz militarne, nawiązujące do wojny Jahwe (Lb 10,9; Sdz 7,15-21). Humbert, La «Terou'a», 29-45; Schwienhorst, Die Eroberung Jerichos, 51.

21 Prawo nie przewidywało żadnych wyjątków, a nawet nakazywało bezlitosne zachowanie wobec ludności Kanaanu. Crowell, Good Girl, Bad Girl, 5-6.

22 Creach, Joshua, 65-66.

23 Dwie tradycje mogą być przejawem dwóch tendencji zachowanych przez redaktora deuteronomistycznego. Pierwsza zawarta w 6,23 nawiązująca do wiernego wypełnienia prawa, stawia Rachab poza obozem izraelskim, choć przysięga zostaje przez Jozuego zachowana. Druga prezentuje Rachab, jako kobietę, należącą przez wiarę oraz czyny do nowego ludu, do Izraela. Schwienhorst, Die Eroberung Jerichos, 105-116, Wiersbe, Be Strong, 78; Woudstra, The Book of Joshua, 115. 
szczelnie zamknięte $(2,7.15)$, a na końcu udziela im wskazówek, jak bezpiecznie mogą wrócić do obozu izraelskiego $(2,16)$.

Postępowanie Rachab warto skonfrontować z działaniem mieszkańców Jerycha, którzy chociaż obawiają się Boga Izraela, gdyż słyszeli o wielkich dokonaniach Jahwe i Jego ludu (2,10-11), nie kapitulują, ale podejmują aktywną walkę z najeźdźcą ${ }^{24}$. Mieszkańcy Jerycha nie tylko ograniczają się do działań obronnych wewnątrz miasta, ale demonstrują siłę i pewność, próbując pochwycić wywiadowców podczas ich powrotu do obozu (2,6-7). Nieustępliwość i upór mieszkańców miasta jest dostrzegalny w uporczywych poszukiwaniach, które trwają trzy dni ${ }^{25}$.

Na tle mieszkańców Jerycha zupełnie odmiennie zostaje ukazana nierządnica Rachab. Poganka obiera zupełnie inną drogę niż jej współziomkowie. Ona również słyszy o wielkich dziełach Boga w Egipcie i w Zajordaniu, i podobnie jak oni czuje strach i przerażenie (2,10-11). Zachowanie Rachab jest jednak zupełnie inne. Rezygnuje ona $\mathrm{z}$ konfrontacji i walki $\mathrm{z}$ Jahwe, zmienia front i opowiada się po stronie Boga Izraela. Potwierdzeniem tego jest zaskakująca sytuacja, w której to właśnie ona, poganka, skazana prawem ḥeremu na zagładę, wypowiada formułę powierzenia ziemi $(2,9)^{26}$. Jej nastawienie przypieczętowane zostaje przez wyznanie wiary, które wprawdzie nie ma charakteru monoteistycznego, ale daje uprzywilejowane miejsce $\mathrm{Bogu}^{27}$. Wyznanie Rachab i jej czyny sprawiają, że nie jest już ona przeciwnikiem Jahwe, ale sojuszniczką przez wiarę w Niego (Hbr 11,31; Jk 2,25). Ta postawa zostaje skonkretyzowana w przymierzu, które zawiera $\mathrm{z}$ wywiadowcami, a przez nich z całym Izraelem. Staje się przez nie autentyczną częścią narodu wybranego i beneficjentką ziemi

24 Słowa: $m \hat{u} \bar{g}$ „topnieć”, êmāh „strach”, māsas „rozpłynąć sie” podkreślają strach mieszkańców Kanaanu oraz nawiązują do wojny Jahwe. McCarthy, Some Holy War, 228-300 .

25 Droga od Jerycha do Jordanu, to zaledwie kilka kilometrów. Trzydniowy czas pościgu, choć zgodny z praktykami wojennymi tamtej epoki wskazuje na nieustępliwość i dokładność poszukiwań. Weinfeld, The Promise of the Land, 142-143.

26 Formuła ziemi wypowiedziana przez Rachab poprzedzona jest czasownikiem yāda ${ }^{\circ}$ „wiem”, który w tym wypadku oznacza wiedzę pochodzącą od Boga opartą na wierze. Rachab wypowiada więc swoje wewnętrzne przekonanie, które jest owocem tego, co usłyszała o Bogu Jahwe oraz o narodzie wybranym; Botterweck, «yād $\underline{a}$ "», THDOT, t. V, 448-481; Boling, Joshua, 146; Harstad, Joshua, 125.

27 Trudno przypuszczać, że poganka, Kananejka, która żyła w kręgu kulturowym akceptującym politeizm, nagle z łatwością przechodzi na monoteizm. Sam naród wybrany dochodził do tej prawdy stopniowo. Również formuła wyznania wydaje się kontestować monoteistyczną wiarę Rachab. Lerner, Rahab the Harlot, 52-55; Soggin, Israel in the Biblical Period, 49-54; Albertz, Monotheism and Violence, 385. 
obiecanej $(2,12-14.17-20)^{28}$. Przez swoją wiarę, potwierdzoną przez czyny, Rachab wybawia nie tylko siebie, ale również swoją rodzinę.

Redaktor deuteronomistyczny kładzie również nacisk na sytuację życiową Rachab, dlatego zręcznie przemyca w tekście informacje o jej statusie społecznym. Rachab przedstawiona jest jako zônāh „nierządnica, prostytutka” $(2,1)$. Mieszkająca na obrzeżach miasta, w jego murach $(2,15)$, trudniąca się rolnictwem, czego potwierdzeniem jest len na jej dachu $(2,6)$, zatroskana o własną rodzinę (2,12-13), a więc kobieta o bardzo nędznym statusie społecznym, która przez niesprawiedliwość społeczną musi wciąż zabiegać o przeżycie ${ }^{29}$. Wyzwolenie z takiej niewoli oraz ucisku mogli przynieść tylko Izraelici, z którymi zawiera ona przymierze i przez to staje się częścią wolnego ludu Bożego. Jej nowy status nakreślony jest $\mathrm{w}$ epilogu jej dziejów ukazanym po podboju Jerycha (6,23-25). Przymierze, które zawiera ze szpiegami (2,12-14.17-20), włącza ją we wspólnotę narodu wybranego i pozwala jej być beneficjentką dóbr, którymi Bóg go obdarza $(6,25)$.

W świetle narracji o wywiadowcach w Jerychu staje się oczywiste, że Rachab zostaje ocalona od prawa ḥeremu razem ze swoją rodziną przez swoją niezwykłą postawę wiary, która potwierdzona zostaje konkretnymi czynami, mającymi na celu ocalenie wywiadowców ${ }^{30}$. Rachab jako poganka, nierządnica, mieszkanka Jerycha, nie przyjmuje postawy swoich współziomków, ale wybiera zupełnie inną drogę przyjęcia Boga Jahwe, jego wyroków, przez przymierze przystaje do narodu wybranego, odmieniając zupełnie los swojej rodziny. Na tle mieszkańców Jerycha, którzy w konfrontacji z Bogiem Jahwe i Jego ludem tracą wszystko, Rachab jawi się, jako cierpiąca materialną biedę kobieta, która z tragicznej sytuacji materialnej, niemal niewolniczej, staje się częścią ludu Bożego, cieszy się wiarą w Jahwe, wybawia siebie i swoją rodzinę i odzyskuje wolność.

28 Opis zawarcia przymierza w narracji o wywiadowcach ma podwójną odsłonę. Rachab kończąc wyznanie wiary w Jahwe, powołując się na hesed „miłosierdzie”, jakiego doświadczyli od niej wywiadowcy i prosi na zasadzie odpłaty o miłosierdzie $(2,12-14)$. Druga osłona zawieranego przymierza opiera się na bardziej jurydycznym sformułowaniu warunków (2,17-20). Clark, The Word Hesed, 173; Campbell, Rahab's Covenant, 243-244.

29 Dokładna analiza tekstu wskazuje, że Rachab nie była nierządnicą sakralną, a jej profesja wiązała się raczej z niedostatkiem. Na taki jej status wskazuje również mieszkanie w murach, czyli na obrzeżach miasta gdzie zamieszkiwała uboga ludność, próbująca zarobić na swoje utrzymanie przez drobne prace rolnicze. Rachab nie wspomina o swojej własnej rodzinie: o dzieciach, mężu. Życie kobiety na Bliskim Wschodzie bez męża i dzieci było bardzo trudne. Natomiast dźwiga na barkach troskę o swoich rodziców i rodzeństwo $(2,12-13)$. Sicre, Giosuè, 89; Robinson, Rahab of Canaan - and Israel, 264-265; Borowski, Daily Life, 31-32.44; Dziadosz, Droga do wiary poganki, 271-293.

30 Wiersbe, Be Strong, 78. 


\section{Stracony Akan}

Podobny związek wątkowy dostrzegany jest pomiędzy opisem zdobycia Jerycha (6,1-27) a historią Akana (7,1-26). Koncepcja wojny Jahwe, która tak wyraźnie została uwydatniona w opowiadaniu o podboju Jerycha $(6,1-7)$, zdecydowanie kontrastuje z nieudanym opisem podboju $\mathrm{Aj}(7,2-5)$. Choć schemat instytucji wojny Jahwe w batalii o Jerycho został wcześniej opisany, warto zwrócić w tej narracji uwagę na nakaz Jozuego dotyczący prawa heremu (6,17-18). Nakaz ten stanowi swoiste preludium, specyficzną zapowiedź opowiadania o nieudanym podboju Aj i grzechu Akana (7,1-26). Zlecając Izraelitom wykonanie heremu, Jozue przestrzega ich przed zabraniem czegokolwiek z tych rzeczy, które mają zostać poddane klątwie $(6,18)$. W krótkim poleceniu Jozuego dostrzegalna jest teologia ḥeremu. Nakaz ten wykonany jest dla Jahwe: hêrem hî̀ wok̂kol-ăšer bāh lyhwh, co podkreśla odcień kultyczny tego prawa, które mają wykonać Izraelici ${ }^{31}$. Poza tym Jozue wskazuje na kolektywne konsekwencje niedochowania tego prawa: ściągnięcie przekleństwa na obóz izraelski oraz sprowadzenie nieszczęścia. Ukradziona rzecz, należąca do Jahwe sprawia że człowiek, który dopuszcza się takiego przewinienia ściąga na siebie klątwę, a grzech, który popełnia uderza w całą wspólnotę Izraela ${ }^{32}$.

Przestroga Jozuego stanowi czytelną aluzję do historii Akana, którego występek jest nie tylko jego osobistym przewinieniem, ale również grzechem całego Izraela. Czasownik mā'al „niewierność, zdrada” ukazuje charakter grzechu, jakiego dopuścili się Izraelici. Słowo to oznacza niewierność, złamanie prawa i przymierza ${ }^{33}$. Redaktor jednoznacznie więc wskazuje, że złamanie prawa ḥeremu jest niewiernością okazaną Jahwe i złamaniem przymierza z Nim zawartego oraz mocno akcentuje, że zgubny czyn Akana ma nie tylko wpływ na niego, ale również na cały naród wybrany. Szczegółowy opis genealogii Akana uwydatnia prawdę, że grzech przez niego popełniony ma znaczenie kolektyw$n e^{34}$.

31 Z jednej strony wymiar kultyczny zostaje zrealizowany w złożeniu ofiary ze wszystkiego dla Jahwe, ale $\mathrm{z}$ drugiej strony realizuje się on w posłuszeństwie w wykonaniu tego prawa. Woudstra, The Book of Joshua, 113; Hess, Joshua, 145-146.

32 Hess, Achan and Achor, 89-91.

33 Czasownik, który jest charakterystyczny dla teologii deuteronomistycznej odnosi się do relacji dwóch podmiotów: Boga i człowieka lub ludzi i oznacza zerwanie i zniszczenie tej relacji. Ringgren, «mā'al», THDOT, t. VIII, 461-462; Butler, Joshua, 83; Woudstra, The Book of Joshua, 120-121.

34 Begg, The Function of Josh 7,1-8,29, 321-322. 
Opis pierwszej wyprawy przeciwko Aj jest wyjątkowy na tle całej Księgi Jozuego. Z pozoru wszystko dzieje się według opisywanego schematu prowadzenia wojny Jahwe: Jozue wysyła wywiadowców, aby zbadali Aj $(7,2)$, szpiedzy wracają z pomyślnym raportem $(7,3)$, wojsko wyrusza, przekonane o pewnym zwycięstwie $(7,4)$ i w tym momencie okazuje się, że bitwa przebiega zupełnie inaczej niż w Jerychu. Izraelici zostają pokonani, a nawet przepędzeni przez mieszkańców Aj $(7,4-5)^{35}$. Dopiero niepomyślny koniec wyprawy pozwala zauważyć, że brakuje w niej czegoś niezwykle istotnego, brakuje głosu Jahwe, jego nakazów, strategii, formuły powierzenia ziemi. Brakuje Jozuego, jako wodza dowodzącego atakiem i wydającego rozkazy $(6,2 ; 7,4)$, wszystko opiera się na kalkulacjach i przekonaniu człowieka, nawet raport składany Jozuemu jest typowo militarny, określający słabe punkty wroga $(7,3)$, w odróżnieniu od raportu szpiegów z Jerycha, na wskroś teologicznego, potwierdzającego zaufanie w Boga Jahwe $(2,24)^{36}$.

Taki obrót wydarzeń powoduje strach ludu. Stan ten oddany jest za pomocą czasownika māsas „topnieć”, który wcześniej opisywał strach mieszkańców Kanaanu i Jerycha przed Izraelem i należy do słownictwa wojny Jahwe $(2,11 ; 7,5)^{37}$. Konkluzja, jaka wyłania się powoli z całej historii, jest jasna. Teraz to Izrael jest ogarnięty strachem, bo rozpalił gniew Boga $(7,1)$, dlatego Jahwe go opuścił, nie walczy już z Izraelitami, a nawet występuje przeciw nim powodując ich klęskę i strach w ich sercach ${ }^{38}$.

Dalsza część historii $(7,6-26)$ stanowi teologiczną wykładnię oraz uzasadnienie nieudanej misji przeciwko Aj. Wydarzenia, które nie są pomyślne dla Izraela, nakazują postawić pytanie o przyczyny klęski, pada ono z ust Jozuego (7,7-9). Pierwszą jego reakcją jest wyrażenie głębokiego smutku i żalu39. Słowa modlitwy Jozuego przypominają narzekania ludu na pustyni: robi wyrzuty Bogu, utyskując nad tym, że Jahwe przeprowadził ich przez Jordan, a teraz wiedzie ich ku zagładzie ${ }^{40}$. Szczególne jednak istotny w kontekście wojny Jahwe jest zwrot, którego Jozue używa w czasie mowy do Boga lātēt 'ōtannû bayad

35 Berman, The Making of the Sin, 122-124.

36 Creach, Joshua, 69.

37 Boling, Joshua, 223.

38 Mitchell, Together in the Land, 70.

39 Wydaje się, że taki sposób zachowania Jozuego nie jest uznaniem winy ludu, ale raczej zachowaniem człowieka, który do końca nie rozumie, za co lud został ukarany i jest przekonany o jego niewinności. Howard, Joshua, 173.

40 Przeprowadzenie przez Jordan w teologii deuteronomistycznej, ma szczególne znaczenie, gdyż przekroczenie Jordanu jest równoznaczne z wejściem do ziemi obiecanej oraz realizowaniem obietnicy ziemi. 
hà 'émōrî $(7,8)$. Przypomina on formułę powierzenia ziemi, tym razem to nie Izraelici otrzymują zapewnienie zwycięstwa i zdobyczy, ale mieszkańcy Kanaanu. Izraelici czują się zagrożeni przez otaczających ich wrogów ${ }^{41}$.

Bóg, odpowiadając na modlitwę Jozuego, wyjaśnia, że powodem tych wydarzeń jest grzech popełniony przez Izraelitów. Waga tego grzechu zostaje uwydatniona przez pięć czasowników, które są określeniem działań Izraelitów:

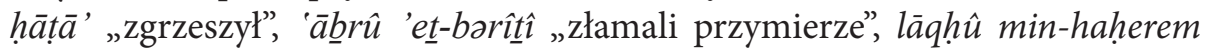
„wzięli z heremu”, a dokładnie gānaḅ̂u „ukradli” oraz kihăšŝu „oszukali” $(7,11)^{42}$. Izraelici ściągnęli na siebie klątwę hāŷ̂u loḥêrem, dlatego jedyną drogą do oczyszczenia jest wykorzenienie z ludu tego, co klątwę sprowadziło. Jozue otrzymuje nakaz dokonania dochodzenia w celu znalezienia winnego, poprzedzony wezwaniem do oczyszczenia ludu, który jest elementem instytucji wojny Jahwe $(7,13-15)^{43}$. Oczyszczenie ludu dokonało się przed przejściem Jordanu i było przygotowaniem do cudów, których Izrael miał być świadkiem $(3,5)$. Na skutek grzechu lud traci możliwość uczestniczenia w wielkich dziełach Jahwe i musi się oczyścić na nowo $(7,13)$. Przeprowadzone dochodzenie pozwala na odkrycie sprawcy $(7,16-18)$. Akan, zachęcony przez Jozuego, sam przyznaje się do zabrania zdobyczy z Jerycha (7,19-21). Rzeczy zagrabione przez Akana są stosunkowo małej wartości: płaszcz z Szinearu, złoty pręt oraz srebro $(7,21)$. Wyraziście zarysowany jest przez to mocny kontrast pomiędzy wartością zabranych rzeczy a oceną grzechu przez autora bliblijnego. Waga grzechu Akana nie jest mierzona wartością i ilością tego, co zabrał, ale tym, że jego czyn był jawnym złamaniem przymierza, niewiernością okazaną Bogu, brakiem czci ${ }^{44}$.

Przeprowadzony proces, potwierdzony dowodami, prowadzi przede wszystkim do oddania rzeczy prawowitemu właścicielowi, czyli Jahwe $(7,23)$. Dopiero kolejnym krokiem jest wymierzenie sprawiedliwej kary. Akan zostaje ukamienowany, a następnie wraz ze swoją rodziną i ukradzionymi rzeczami spalony $(7,24-26)^{45}$.

41 Czasownik sāb $\underline{b} \underline{b}$ „okrążać” wielokrotnie występował w podboju Jerycha i był znakiem siły Izraela i potrzasku, w jakim znaleźli się wrogowie (6,3-7.11-15), teraz to wrogowie, Kananejczycy otaczają będącego w potrzasku Izraela $(7,9)$. Harstad, Joshua, 311.

42 Mitchell, Together in the Land, 68-69.

43 Dostrzegalny jest tutaj podwójny aspekt heremu: kultyczny, który przejawia się w oczyszczeniu Izraelitów, tak by byli gotowi na obecność Jahwe oraz pokutny, zło dokonane przez Akana, rozpalony gniew Boga, złamane przymierze domaga się sprawiedliwości. Butler, Joshua, 85.

44 Niditch, War in the Hebrew Bible, 56-57.

45 Najcięższy grzech w Księdze Powtórzonego Prawa czyli idolatria, domaga się kary tylko osoby winnej, nie wspomina się o ukaraniu rodziny, czy bliskich (Pwt 13,2-13; 17,2-5). Trudno uznać grzechu Akana jako podlegający karze kolektywnej (Pwt 13,13-19). 
Choć kara wymierzona Akanowi jest często kwestionowana jako zbyt okrutna i niesprawiedliwa szczególnie w odniesieniu do jego najbliższych, warto zwrócić uwagę, że ma ona wieloraki wymiar. Wprawdzie wartość przedmiotów była niewielka, to jednak sama istota grzechu jest niezmiernie poważna. Oszukanie Jahwe, okradzenie go z czci i chwały, złamanie przymierza w momencie tak ważnym, gdy Bóg spełnia obietnice, daje ziemię, a sami Izraelici mogą czuć jego wszechmocną obecność, czyni to przewinienie jeszcze cięższym $^{46}$. W pierwszym momencie wydaje się, że kara, którą ponosi Akan jest nieadekwatna do winy, jaką popełnił. Strata życia, za kilka przedmiotów o średniej wartości wydaje się aż nadto sroga. Jednak w konfrontacji z postępowaniem Izraela wobec pogan, którzy nie znają Jahwe, człowiek trwający w przymierzu z Bogiem, korzystający z jego wszechmocy i dobroci, powinien mieć postawione nieco wyższe wymagania moralne i religijne, a przez to i większą karę niż poganie. Pozostaje jeszcze kwestia pozbawienia życia rodziny Akana $(7,25)$. Na początku opowiadania redaktor deuteronomistyczny dwukrotnie podkreśla, że grzech indywidualny odbija się na całej społeczności Izraela, dotyka rodziny, rodu, pokolenia $(7,1)$. Akan, zabierając to, co było heremem i co miało zostać dane Bogu (złoto i srebro miało być przeznaczone dla Pana), ściągnął ḥerem na siebie samego oraz na swoją rodzinę ${ }^{47}$. Trudno uciec od analogii pomiędzy Rachab i Akanem, tak jak przez wiarę jednej osoby można ocalić całą rodzinę, tak niewierność jednej osoby sprowadza śmierć na całą rodzinę.

\section{Podsumowanie}

Przeprowadzona powyżej analiza pozwala potwierdzić, że historie o Rachab (2,1-24) oraz Akanie (7,1-26) zajmują szczególne miejsce w kompozycji Księgi Jozuego, pogłębiając wykładnię koncepcji wojny Jahwe i prawa heremu. Redaktor deuteronomistyczny zdecydowanie poszerza rozumienie instytucji wojny Jahwe, która w świetle Księgi Jozuego mogłaby być oceniana przez pryzmat

Jedynym fragmentem, do którego może nawiązywać przewinienie Akana jest Pwt 7,26. Sicre, Giosuè, 171.

46 Nie można wykluczyć, że kara, która dosięga Akana jest uformowana na zasadzie odpłaty i ma na celu podkreślić wielkość grzechu. Sicre, Giosuè, 174.

47 Wprawdzie rodzina Akana nie była odpowiedzialna za zabranie przedmiotów obłożonych klątwą z Jerycha, trudno jednak przypuszczać, że nic nie wiedziała, o ukrytym skarbie pod namiotem. Podobnie jak Akan, który wyznaje winę, dopiero wtedy, gdy już wskazano na niego, tak samo cała rodzina milczy, a więc w jakiś sposób popiera zło. Berman, The Making of the Sin, 130-131; Woudstra, The Book of Joshua, 130-131. 
chciwości i zachłanności Izraela, mającego na celu zdobycie ziemi oraz wytracenie wszystkich mieszkańców.

W omawianych narracjach został zaakcentowany religijny, kultyczny oraz prawny wymiar wojny Jahwe. W wymiarze religijnym i prawnym tekst przedstawia ją jako walkę o prawdziwą wiarę, wolność, wierność przymierzu i przynależność do narodu wybranego. Przez obranie konkretnej postawy: wiary w Boga, której przykładem jest Rachab lub niewierności - Akan, człowiek albo przyłącza sie do pochodu zwycięskiego Boga, narodu wybranego oraz staje się beneficjentem dóbr, albo okazuje się przeciwnikiem Jahwe, z którym podejmuje walkę i wskutek tego skazuje się na klęskę i wszystko traci.

Absolutną nowością, jaką wprowadza redaktor deuteronomistyczny, jest kwestia kogo może dotyczyć nakaz ḥeremu. W świetle tych dwóch historii nie można już twierdzić, że święta wojna, a więc również ḥerem są wymierzone przeciwko poganom, którzy mocą tego nakazu przeznaczeni są do anihilacji. Ocalona Rachab i ukamienowany Akan są najlepszym przykładem, że herem dotyczy tych, którzy sprzeciwiają sie Bogu i jego woli, niezależnie od tego, czy są poganami czy należą do narodu wybranego.

\section{Bibliografia}

«tahat

Albertz R., «Monotheism and Violence: How to Handle a Dangerous Biblical Tradition». w: J. van Ruiten, J. C. de Vos (ed.), The Land of Israel in Bible, History, and Theology, Boston 2009.

Begg C.T., «The Function of Josh 7,1-8,29 in the Deuteronomistic History», Bib 67 (1986) s. 320-334.

Berman J., «The Making of the Sin of Achan (Joshua 7)», Biblinterp (2; 2014) s. 115-131.

Boling R.G., Joshua. A New Translation with Notes and Commentary (AncB 6; New York 1982).

Borowski O., Daily Life in Biblical Times (ABSt 5; Atlanta 2003).

Botterweck G.J., «yā $\underline{d} a$ »

Butler J.G., Joshua. The Conqueror of Canaan (BBS 13; Clinton 1996).

Butler T.C., Joshua (WBC 7; Dallas 1984).

Campbell K.M., «Rahab’s Covenant: A Short Note on Joshua ii 9-21», VT 22 (2; 1972) s. $243-244$.

Clark G.R., The Word Hesed in the Hebrew Bible (JSOT.S 157; Sheffield 1993).

Craigie P.C., The Problem of War in the Old Testament (Grand Rapids 1981).

Creach J.F., Joshua (IBDTP; Louisville 2003).

Crowell B.L., "Good Girl, Bad Girl: Foreign Women of the Deuteronomistic History in Postcolonial Perspective», Biblinterp $21(1 ; 2013)$ s. 1-18.

Curtis A.H., Joshua (Sheffield 1998). 
Dziadosz D., «Droga do wiary poganki Rachab. Teologiczna lektura Joz 2,1-24», BPTh 6 (2013) s. 271-293.

Dziadosz D., «Teokratyczna historiografia Izraela, czyli kim był deuteronomista i jego dzieło», CollTh $74(4 ; 2004)$ s. 5-24.

Geoghegan J.C., "„Until this Day” and the Preexilic Redaction of the Deuteronomistic History », JBL 122 (2003) s. 201-227.

Hamlin E.J., Inheriting the Land. A Commentary on the Book of Joshua (ITC; Grand Rapids 1983).

Harstad A.L., Joshua (ConCom; Saint Louis 2004).

Hess R.S. "Achan and Achor: Names and Wordplay in Joshua 7» (HAR 14 (1994) s. 89-98.

Hoffman Y., «The Deuteronomistic Concept of the Herem», ZAW 111 (1999) s. $196-210$.

Howard D.M. Jr., Joshua (NAC 5; Nashville 1998).

Humbert P., La «Terou'a». Analyse d'un rite biblique (RTFPL 23; Neuchatel 1946).

Jones G.H., «The Concept of Holy War», w: R. E. Clements (ed.), The World of Ancient Israel. Sociological, Anthropological and Political Perspectives Essays by Members of the Society for Old Testament Study (Cambridge 1989) s. 299-321.

Lerner B.D., «Rahab the Harlot and Other Philosophers of Religion», JBQ $28(1 ; 2000)$ s. 52-55.

Lilley J.P.U., "Understanding the Herem», TynB 44 (1; 1993) s. 169-177.

Lind M.C., Yahweh Is a Warrior. The Theology of Warfare in Ancient Israel (A Christian Peace Shelf Selection; Scottdale - Kitchener 1980).

Lohfink N., «hāram», THDOT, t. V, s. 180-198.

McCarthy D.J., «Some Holy War Vocabulary in Joshua 2», CBQ 33 (1971) s. 228-300.

Miller P.D., The Divine Warrior in Early Israel (HSM 5; Cambridge 1973).

Mitchell G., Together in the Land. A Reading of the Book Joshua (JSOT.S 134; Sheffield 1993).

Newman M.L., «Rahab and the Conquest», w: J. T. Butler, E. W. Conrad, B. C. Ollenburger (ed.), Understanding the Word. Essays in Honor of Bernhard W. Anderson (JSOT.S 37; Sheffield 1985).

Niditch S., War in the Hebrew Bible. A Study in the Ethics of Violence (Londres-New York 1993).

von Rad G., Holy War in Ancient Israel (Grand Rapids 1991).

Ringgren H., «mà'al», THDOT, t. VIII, s. 460-463.

Robinson B.P., «Rahab of Canaan - and Israel», SJOT 23 (2; 2009) s. 257-273.

Römer T., de Pury A., «Deuteronomistic historiography (dh): History of research and debated issues», w: A. De Pury, T. Ch. Römer, J.-D. Macchi (ed.), Israel Constructs Its History. Deuteronomistic Historiography in Recent Research (JSOT.S 306; Sheffield 2000) s. 24-141.

Rowlett L., Joshua and the Rhetoric of Violence. A New Historicist Analysis (JSOT. S 226; Sheffield 1996).

Schwienhorst L., Die Eroberung Jerichos. Exegetische Untersuchung zu Josua 6 (SBS 122; Stuttgart 1986). 
Sicre J.L., Giosuè (ComBib; Roma 2004).

Soggin J., Israel in the Biblical Period. Institutions, Festivals, Ceremonies, Rituals (Edinburg - New York 2001) s. 49-54.

Strange J., "The Book of Joshua: Origin and Dating», SJOT 16 (2002) s. 44-51. de Vaux R., Instituciones del Antiguo Testamento (BHer 63; Barcelona 1964).

Weinfeld M., The Promise of the Land. The Inheritance of the Land of Canaan by the Israelites (TLJS 3; Berkeley-Los Angeles-Oxford 1993).

Wiersbe W.W., Be Strong (BCS 34; Wheaton 1996). 